\title{
Azospirillum brasilense interaction effects with captan and thiodicarb on the initial growth of corn plants
}

\author{
Gabriel Felipe Vogel $^{1}$, Rubens Fey ${ }^{1}$ \\ ${ }^{1}$ Universidade Federal da Fronteira do Sul, Campus Laranjeiras do Sul, Laranjeiras do Sul, Paraná, Brasil. E-mail: \\ gabrielfelipevogel@gmail.com, rubens.fey@uffs.edu.br
}

Received: 19/10/2018; Accepted: 06/06/2019.

\section{ABSTRACT}

The application of biological products containing diazotrophic bacteria in the seed has been highlighted as an alternative to reduce the use of nitrogen fertilizers; however, the chemical treatment of the seeds may negatively affect the survival rate of these microorganisms in the soil. The effects of the application of captan (fungicide) and thiodicarb (insecticide) in association with the inoculation of Azospirillum brasilense were investigated in this study for the corn crop. The research was conducted under greenhouse conditions at Universidade Estadual do Centro-Oeste (UNICENTRO), in Guarapuava, Paraná, Brazil, and under laboratory conditions at the Universidade Federal da Fronteira Sul (UFFS), in Laranjeiras do Sul, Paraná, Brazil. A completely randomized experimental design with eight treatments and four replicates was used. The treatments were as follows: control; A. brasilense; captan; thiodicarb; captan + thiodicarb; A. brasilense + captan; A. brasilense + thiodicarb; A. brasilense + captan + thiodicarb. The germination and seedling growth rates were evaluated in the laboratory. In the greenhouse were measured the growth of the roots and shoots until the V8 corn growth stages. The use of A. brasilense alone resulted in higher plant growth when compared to the control treatment, whereas the association of A. brasilense with captan and thiodicarb resulted in a similar response to the uninoculated and control treatments. These results suggest that there was a possible toxic effect of seed treatment with these products. The use of captan and thiodicarb interfere in the interaction of diazotrophic bacteria with root growth, affecting the germination rate and initial corn growth.

Keywords: Zea mays L., diazotrophic bacteria, compatibility with seed treatment, inoculation in grasses crops, toxicity of pesticides.

\section{Efeitos da combinação de Azospirillum brasilense com captana e thiodicarb no desenvolvimento inicial de milho}

\section{RESUMO}

A aplicação de produtos biológicos contendo bactérias diazotróficas na semente tem se destacado como alternativa para reduzir o uso de fertilizantes nitrogenados; no entanto, o tratamento químico das sementes pode afetar negativamente a taxa de sobrevivência desses microorganismos no solo. Este estudo objetivou avaliar os efeitos do fungicida captana e do inseticida thiodicarb com a Azospirillum brasilense na cultura do milho. O estudo foi conduzido em ambiente protegido na Universidade Estadual do Centro-Oeste (UNICENTRO), Guarapuava-PR, e em laboratório na Universidade Federal da Fronteira Sul (UFFS), Laranjeiras do Sul-PR. O delineamento adotado foi inteiramente casualizado, com oito tratamentos e quatro repetições, sendo: testemunha; A. brasilense; captana; thiodicarb; captana + thiodicarb; A. brasilense + captana; A. brasilense + thiodicarb; A. brasilense + captana + thiodicarb. Em laboratório foram realizadas análises de germinação e desenvolvimento de plântulas. Em ambiente protegido foram analisados o sistema radicular e a parte aérea até V8. De modo geral, o uso isolado da $A$. brasilense apresentou maior desempenho em relação à testemunha, sendo que a associação com captana e thiodicarb promoveu comportamento idêntico aos tratamentos com ausência da bactéria e da testemunha, inferindo um possível efeito tóxico advindo do tratamento de sementes com estes produtos. Concluiu-se que o uso captan e thiodicarb interferiu na interação da bactéria com o sistema radicular, afetando o processo de germinação e o desenvolvimento inicial do milho.

Palavras-chave: Zea mays L., bactérias diazotróficas, compatibilidade com tratamento de sementes, inoculação em gramíneas, toxidez por agrotóxicos. 


\section{Introduction}

The use of biological products containing diazotrophic bacteria has become a viable alternative to increase agricultural production due to its ability to reduce the use of chemical fertilizers, improve the activity of soil microorganisms and potentiate the root system growth of plants, among others (Vogel and Fey, 2016). The main benefits of using diazotrophic bacteria are related to the ability to fix atmospheric nitrogen $\left(\mathrm{N}_{2}\right)$ in plant-assimilable forms, especially ammonia, as well as to induce the production of plant growth promoting substances (Franche et al., 2009; Hungria et al., 2010).

Azospirillum brasilense is one of the plants growthpromoting bacteria (PGPB) that has been widely used in the formulation of commercial inoculants in grass species. This is due to its ability to fix atmospheric N, increase the activity of nitrate reductase enzyme, produce plant hormones such as auxins, cytokinins, gibberellins and ethylene, solubilize phosphate, optimize the association between mycorrhizas and plants and act indirectly on growth of phytopathogenic fungi and bacteria of the soil (Reis Junior et al., 2008).

The most common method to apply A. brasilense in crop plants is the use of liquid commercial inoculants in seeds (Hungria, 2011). In addition to this management practice, the use of fungicides and insecticides has also been widely used by farmers, in order to promote the control of seed-borne pathogens and against pest attack in the establishment period of the seedlings. However, the use of these products may have deleterious effects on soil microbiota, especially diazotrophic bacteria (Dartora et al., 2013). In the soybean crop, studies have reported that the use of phytosanitary products (insecticide and fungicide) can affect the physiological potential of plants and impair root nodulation, reducing the number of nodules by up to $80 \%$, which resulted in a reduction of $20 \%$ in grain yield (Campos et al., 2009).

There are A. brasilense strains that have not been studied for tolerance about the phytosanitary products commonly used in seed treatment, as well as in the initial establishment of plants (Dartora et al., 2013). Thus, the present study aims to investigate the effects of seed treatment with captan (fungicide) and thiodicarb (insecticide) on the effectiveness of $A$. brasilense inoculation in the initial growth of corn plants.

\section{Material and Methods}

The experiments were conducted under greenhouse conditions from September to December 2014, at the Universidade Estadual do Centro-Oeste (UNICENTRO), in Guarapuava, Paraná, Brazil, and in laboratory conditions from February to June 2015 at the Universidade Federal da Fronteira Sul (UFFS), in Laranjeiras do Sul, Paraná, Brazil.
A completely randomized experimental design with eight treatments and four replicates was used. The treatments were constituted by the association of the use of the fungicide captan, the insecticide thiodicarb and the inoculation of A. brasilense (Ab-V5 and Ab-V6 strains) at the concentration of $2.0 \times 10^{8}$ viable cells $\mathrm{mL}^{-1}$, and are as follows: i) control; ii) A. brasilense; iii) captan; iv) thiodicarb; v) captan + thiodicarb; vi) $A$. brasilense + captan; vii) A. brasilense + thiodicarb; and, viii) $A$. brasilense + captan + thiodicarb.

Concentrations of the products used were: Captan (240 $\mathrm{g}$ of the commercial product Orthocide ${ }^{\circledR} 500$ for $100 \mathrm{~kg}$ of corn seed), Thiodicarb $(2.0 \mathrm{~L}$ of the commercial product Saddler ${ }^{\circledR} 350 \mathrm{SC}$ for $100 \mathrm{~kg}$ of seed), and inoculant containing A. brasilense $(300 \mathrm{~mL}$ of the commercial product Nitro $1000^{\circledR}$ Gramíneas for $50 \mathrm{~kg}$ of seeds). All concentrations were applied according to the manufacturers' recommendations.

\section{Seed germination and seedling growth}

Germination test: 50 seeds of corn cultivar IPR 114 were distributed in two sheets of germitest paper, moistened adequately with distilled water, in a volume equivalent to 2.5 times the weight of the dry paper. The seeds then were covered with a third sheet of paper and rolled up.

The four rolls, corresponding to the replicates, were grouped by treatment and placed in the germinator at $25{ }^{\circ} \mathrm{C}\left( \pm 1{ }^{\circ} \mathrm{C}\right)$ in an upright position to germinate. Evaluations were performed at the fourth (first count of germination test) and eighth days (total germination percentage) after the test installation. The results expressed in percentage of normal and abnormal seedlings, and dead seeds, according to the recommendations of Seed Analysis Rules (Brasil, 2009). The normal seedlings were considered those with a root system larger than $20 \mathrm{~mm}$ in length and with well-developed coleoptile.

Seedling growth: the root and total seedling length were measured in 10 normal seedlings randomly obtained after the count of the total germination $\left(8^{\text {th }}\right.$ day) using a meter scale. The results were expressed in centimeter $(\mathrm{cm})$. The number of roots was also counted. For the determination of the seedling fresh matter and seedling dry matter, ten normal seedlings randomly obtained at the eighth day were weighed in an analytical balance with an accuracy of $0.001 \mathrm{~g}$, and then seedlings were dried in a forced air circulation oven for three days at $65{ }^{\circ} \mathrm{C}$ and weighed. The results were expressed in $\mathrm{g}$ per seedling.

The Shapiro-Wilk test previously tested the normality of data, and then data were submitted to analysis of variance, and the Dunnet's test compared the means at $5 \%$ probability level. The percentage data was previously transformed into $(\mathrm{x}+0.5)^{0.5}$. All analyses 
were performed using ASSISTAT v. 7.7 software for Windows.

\section{Plant growth under greenhouse conditions}

Soil samples from a Rhodic Hapludox (Latossolo Vermelho distroférrico in the Brazilian classification) were collected in the superficial layer of $0.0-0.20 \mathrm{~m}$ depth. The main chemical properties of the soil are shown in Table 1 . The soil was then placed in $8-\mathrm{L}$ plastic pots and fertilized with $28 \mathrm{mg} \mathrm{dm}^{-3}$ of $\mathrm{P}_{2} \mathrm{O}_{5}$ as simple superphosphate $\left(18 \%\right.$ of $\mathrm{P}_{2} \mathrm{O}_{5}, 25 \%$ of $\mathrm{CaO}$ and $12 \%$ of $\mathrm{S}$ ), and $15 \mathrm{mg} \mathrm{dm}^{-3}$ of $\mathrm{K}_{2} \mathrm{O}$ as potassium chloride $\left(60 \%\right.$ of $\left.\mathrm{K}_{2} \mathrm{O}\right)$. The $\mathrm{N}$ fertilization as urea $(45 \%$ $\mathrm{N})$ was applied in topdressing at sowing, V3 stage, and V6 stage at a rate of 10,35 and $35 \mathrm{mg} \mathrm{dm}^{-3}$ of $\mathrm{N}$, respectively.

Eight corn seeds (Zea mays L., cv. IPR 114) were sown in plastic pots containing clayey soil and, at seven days after emergence, seedlings were thinned down to one per pot. The soil water content was monitored daily and maintained close to the field capacity with daily irrigations. Weed control was performed manually when necessary.
At the V8 growth stage, the plants were harvested, and then the plant height, root length, root volume, leaf area, relative chlorophyll index, fresh and dry matter of leaves, stems, and roots were measured. The shoot and root length were measured using a graduated ruler and expressed in cm plant ${ }^{-1}$. Root volume $\left(\mathrm{cm}^{3}\right.$ plant $\left.^{-1}\right)$ was determined by water displacement using a calibrated cylinder. The leaf area was measured using the leaf area meter LI-3100 ${ }^{\circledR}$ and expressed in $\mathrm{cm}^{2}$ plant $^{-1}$. The relative chlorophyll index was measured by a chlorophyll meter ClorofiLOG ${ }^{\circledR} 1030$-Falker, with three measurements per pot, at the third leaf totally expanded. The plants were separated into leaves, stems, and roots and then weighed. Plant material was dried in an oven for three days at $65{ }^{\circ} \mathrm{C}$ and then weighed in an analytical balance $(0.001 \mathrm{~g})$. The results were expressed in $\mathrm{g}$ plant $^{-1}$.

The Shapiro-Wilk test previously tested the normality of data, and then data were submitted to analysis of variance, and the Dunnet's test compared the means at 5\% probability level. All analyses were performed using ASSISTAT v. 7.7 software for Windows.

Table 1. Some of the soil properties used in the experiment.

\begin{tabular}{|c|c|c|c|c|c|c|c|c|c|c|}
\hline $\mathrm{pH}$ & Organic matter & $\mathrm{P}$ & $\bar{K}$ & $\mathrm{Ca}$ & $\mathrm{Mg}$ & $\mathrm{Al}$ & \multirow{2}{*}{$\begin{array}{c}\mathrm{V} \\
(\%)\end{array}$} & Sand & Silt & Clay \\
\hline$\left(\mathrm{CaCl}_{2}\right)$ & $\left(\mathrm{g} \mathrm{kg}^{-1}\right)$ & $\left(\mathrm{mg} \mathrm{dm}^{-3}\right)$ & \multicolumn{4}{|c|}{$\left(\mathrm{cmol}_{\mathrm{c}} \mathrm{dm}^{-3}\right)$} & & \multicolumn{3}{|c|}{$\left(\mathrm{g} \mathrm{kg}^{-1}\right)$} \\
\hline 6.1 & 42.5 & 10.0 & 0.83 & 5.09 & 1.90 & 0.0 & 77 & 250 & 180 & 570 \\
\hline
\end{tabular}

\section{Results and Discussion}

The use of the captan, thiodicarb, and A. brasilense alone or in combination did not significantly affect ( $\mathrm{p}>$ 0.05 ) the first count of germination test of corn seeds (Table 2). The inoculation of A. brasilense alone or in combination with Captan resulted in a higher total germination percentage compared to the other treatments (Table 2). These results suggest that there was a synergistic effect of this active ingredient with the diazotrophic bacteria on the germination rate. Similar results were reported by Pereira et al. (2009), which showed that the use of Captan did not affect the germination rate of soybean seeds inoculated with diazotrophic bacteria. However, the synergistic effects of this active ingredient on the bacterium were not observed about the formation of normal and abnormal seedlings, i.e., so that their combination resulted in a lower percentage of normal seedlings and a higher percentage of abnormal seedlings compared to control treatment, emphasizing a possible effect of this fungicide. Thus, prolonged exposure of A. brasilense to the fungicide could impair its survival and, consequently, affect the contribution of plant hormones to the initial seed germination process (Vogel and Fey, 2016).

Regarding the insecticide thiodicarb, the use of this active ingredient alone and/or with $A$. brasilense provided similar results in comparison to the control treatment in the germination rate (Table 2). This indicates that there were no beneficial effects from the diazotrophic bacteria, and, thus, causing a possible antagonistic effect of the insecticide on the A. brasilense bacteria. These antagonistic effects on A. brasilense were also observed with other insecticides. Battistus et al. (2014) reported decreases in the formation of colony forming units of this bacterium with an increasing dose of thiamethoxam insecticide.

According to Cassán et al. (2009), the contribution of $A$. brasilense to the germination process and the growth of plants is due to the capacity of the bacterium to produce plant hormones such as gibberellin and auxin, hormones responsible for the germination process of the seeds and for stimulating growth of the plant through cell elongation, respectively. Thus, negative effects on the development of the bacterium may affect the contribution and/or production of plant 
hormones (Fey et al., 2015) and, consequently, compromise the germination rate and plant growth.

The use of $A$. brasilense alone resulted in a higher percentage of total germination, a lower percentage of abnormal seedlings and dead seeds compared to the control treatment (Table 2). These results indicate that A. brasilense contributed to germination and initial corn growth. In addition to the benefits reported by Cassán et al. (2009) of A. brasilense on the germination process and seedling growth, the ability of this bacterium to survive for long periods can be highlighted. Milani et al. (2013) showed that A. brasilense bacteria survived in the inoculated medium for up to 120 hours, without compromising the formation of colony forming units, thus allowing the production of plant hormones for long periods.

About the effects of the combination of the active ingredients with the diazotrophic bacteria on the growth of maize seedlings (Table 3 ), it can be verified that the application of captan $+A$. brasilense and thiodicarb $+A$. brasilense resulted in higher plant height when compared to the control treatment. However, the synergistic effects of captan and thiodicarb active ingredients associated with diazotrophic bacteria do not occur in the other morphological characteristics of maize plants (Table 3).

Although showing similar results for root length, the use of A. brasilense alone provided higher plant height, total seedling length, and the number of roots about the control. However, the application of the active ingredients captan and thiodicarb demonstrated that there was no significant difference between the control about the total seedling length and the number of roots, besides providing smaller roots length.

Azospirillum brasilense can contribute for long periods in the production of plant hormones responsible for the growth of seedlings, especially gibberellic acid and indole-3-acetic acid (IAA) (Reis Junior et al., 2008). However, the activity of certain diazotrophic bacteria can be compromised due to some antagonistic stimulus, such as soil physicochemical conditions and the toxicity of some pesticides (Hungria, 2011).

Table 2. Effects of the application of captan (fungicide) and thiodicarb (insecticide) in association with the inoculation of Azospirillum brasilense on the first count of germination test ( $4^{\text {th }}$ day), total germination percentage ( $8^{\text {th }}$ day), percentage of normal seedlings, abnormal seedlings, and dead seeds of corn (Zea mays L., cv. IPR 114). Laranjeiras do Sul, Paraná, Brazil. 2015.

\begin{tabular}{lccccc}
\hline \multicolumn{1}{c}{ Seed treatment } & $\begin{array}{c}\text { First count of } \\
\text { germination }\end{array}$ & Total germination & $\begin{array}{c}\text { Normal } \\
\text { seedlings }\end{array}$ & $\begin{array}{c}\text { Abnormal } \\
\text { seedlings }\end{array}$ & Dead seeds \\
\hline Control & $(\%)$ & $(\%)$ & $(\%)$ & $(\%)$ & $(\%)$ \\
Azospirillum brasilense & 71 & $93 \mathrm{~b}$ & $79 \mathrm{a}$ & $13 \mathrm{~b}$ & $7 \mathrm{a}$ \\
Captan fungicide & 70 & $97 \mathrm{a}$ & $86 \mathrm{a}$ & $11 \mathrm{~b}$ & $3 \mathrm{~b}$ \\
Thiodicarb insecticide & 68 & $96 \mathrm{~b}$ & $84 \mathrm{a}$ & $11 \mathrm{~b}$ & $4 \mathrm{a}$ \\
Captan + thiodicarb & 69 & $93 \mathrm{~b}$ & $81 \mathrm{a}$ & $15 \mathrm{~b}$ & $4 \mathrm{a}$ \\
A. brasilense + captan & 68 & $92 \mathrm{~b}$ & $76 \mathrm{a}$ & $16 \mathrm{~b}$ & $8 \mathrm{a}$ \\
A. brasilense + thiodicarb & 70 & $98 \mathrm{a}$ & $62 \mathrm{~b}$ & $35 \mathrm{a}$ & $2 \mathrm{~b}$ \\
A. brasilense + captan + thiodicarb & 72 & $91 \mathrm{~b}$ & $76 \mathrm{a}$ & $15 \mathrm{~b}$ & $8 \mathrm{a}$ \\
C.V. $(\%)$ & 67 & $95 \mathrm{~b}$ & $76 \mathrm{~b}$ & $18 \mathrm{~b}$ & $3 \mathrm{a}$ \\
\hline M. & 5.20 & 2.61 & 5.79 & 16.18 & 23.08 \\
\hline
\end{tabular}

Mean followed by the same letter in the column do not differ by Dunnett's test at the $5 \%$ probability level.

Table 3. Effects of the application of captan (fungicide) and thiodicarb (insecticide) in association with the inoculation of Azospirillum brasilense on the plant height, root length, total seedling length, and number of roots of corn seedlings (Zea mays L., cv. IPR 114). Laranjeiras do Sul, Paraná, Brazil. 2015.

\begin{tabular}{|c|c|c|c|c|}
\hline Seed treatment & Plant height & Root length & $\begin{array}{l}\text { Total seedling } \\
\text { length }\end{array}$ & Number of roots \\
\hline & $(\mathrm{cm})$ & $(\mathrm{cm})$ & $(\mathrm{cm})$ & \\
\hline Control & $7.05 \mathrm{~b}$ & $12.20 \mathrm{a}$ & $19.25 \mathrm{~b}$ & $5.45 \mathrm{~b}$ \\
\hline Azospirillum brasilense & $9.33 \mathrm{a}$ & $13.23 \mathrm{a}$ & $22.55 \mathrm{a}$ & $6.48 \mathrm{a}$ \\
\hline Captan fungicide & $7.46 \mathrm{~b}$ & $11.88 \mathrm{a}$ & $19.34 \mathrm{~b}$ & $5.55 \mathrm{~b}$ \\
\hline Thiodicarb insecticide & $6.91 \mathrm{~b}$ & $9.59 \mathrm{~b}$ & $16.51 \mathrm{~b}$ & $4.05 \mathrm{~b}$ \\
\hline Captan + thiodicarb & $8.21 \mathrm{~b}$ & $4.93 \mathrm{~b}$ & $13.14 \mathrm{~b}$ & $3.73 \mathrm{~b}$ \\
\hline A. brasilense + captan & $8.66 \mathrm{a}$ & $7.74 \mathrm{~b}$ & $16.40 \mathrm{~b}$ & $4.18 \mathrm{~b}$ \\
\hline A. brasilense + thiodicarb & $8.74 \mathrm{a}$ & $8.56 \mathrm{~b}$ & $17.30 \mathrm{~b}$ & $4.45 \mathrm{~b}$ \\
\hline A. brasilense + captan + thiodicarb & $8.16 \mathrm{~b}$ & $8.69 \mathrm{~b}$ & $16.84 \mathrm{~b}$ & $5.30 \mathrm{~b}$ \\
\hline$\overline{\mathrm{CV}(\%)}$ & 8.98 & 9.13 & 7.90 & 8.65 \\
\hline
\end{tabular}

Mean followed by the same letter in the column do not differ by Dunnett's test at the 5\% probability level. 
Research conducted by Gallori et al. (1991) and Mohiuddin and Mohammed (2013) reported the ability of the captan active ingredient to reduce bacterial growth and negatively affect nitrogenase activity. This inference corroborates the results obtained in this study. However, the benefits of inoculation of A. brasilense alone on the growth of the root system (Table 3) are highlighted in this study. According to Fibach-Paldi et al. (2012), the use of A. brasilense in agriculture on a commercial scale has been expressive due to the bacterium's ability to adapt to the rhizosphere habitat, promoting morphological changes in its structure, such as increase in length and number of roots and, consequently, promoting plant growth, as observed in this study. There was no difference between the means in this study for fresh matter and dry matter of corn seedlings.

Regarding the growth of the plants under greenhouse conditions (Table 4), it can be verified that the use of $A$. brasilense alone provided greater root length, root volume, fresh matter and dry matter of corn roots compared to the control treatment. However, treatments with the application of the active ingredients captan and thiodicarb promoted similar results about the control. Thus, it was possible to infer in this study that the use of chemical seed treatment provided antagonistic effects on the activity of A. brasilense on root development. The antagonistic effects of chemical seed treatment on the benefits of diazotrophic bacteria can be observed in other crops. Kintschev et al. (2014) report that the use of carboxin, thiram, and captan negatively affect the formation of nodules, resulting in decreases in grain yield of dry bean crops. For the soybean crop, the use of active ingredients containing captan, carboxin + thiram and thiamethoxam resulted in thinner roots, with lower length and low presence of nodules (Castro et al., 2008; Pereira et al., 2009).

According to Reis Junior et al. (2008), the increases attributed to the root system from $A$. brasilense are mainly due to its ability to produce plant hormones, especially indole-acetic acid (AIA), which stimulate modifications in some root morphological characteristics, promoting an increase in length of the root system, formation of root hairs and elevation in the rate of appearance of secondary roots, thus reflecting on the increase of the surface area of the root system and, consequently, on the increase of the volume of explored soil.

The negative effects on the efficiency of $A$. brasilense about the root system, due to the antagonistic effects of the chemical treatment of seeds, negatively affected the shoots of the corn plants (Table 5). In this study, the use of $A$. brasilense alone promoted higher results of relative index of chlorophyll, leaf area, dry matter of leaves, stems and total when compared to the control, while the presence of the fungicide and insecticide in an isolated and/or joint, resulting in a similar response to the control.

The lowest values obtained in the treatments inoculated with $A$. brasilense in the presence of captan and thiodicarb (Table 5) could be due to the low assimilation of nitrogen by the plant due to the limitation of the growth of the root system (Table 4). Nitrogen stands out as an essential element in plant nutrition, being constituent of enzymes and structural components, assimilated in the form of ammonium $\left(\mathrm{NH}_{4}{ }^{+}\right)$and nitrate $\left(\mathrm{NO}_{3}{ }^{-}\right)$through mass flow in the root system; thus, a low assimilation of this nutrient and its deficiency in plant tissues results in a lower accumulation of dry matter in the plant.

The relative index of chlorophyll is effective to indirectly evaluate the concentration of chlorophyll and the nitrogen status of the leaves (Ferreira et al., 2015). The antagonistic effects of fungicides in this study on the ability of $A$. brasilense to provide nitrogen and produce plant hormones responsible for root growth influenced the assimilation and the amount of nitrogen present in the plant.

Table 4. Effects of the application of captan (fungicide) and thiodicarb (insecticide) in association with the inoculation of Azospirillum brasilense on the root length, root volume, root fresh matter, and root dry matter of corn seedlings (Zea mays L., cv. IPR 114). Guarapuava, Paraná, Brazil. 2014.

\begin{tabular}{lcccc}
\hline \multicolumn{1}{c}{ Seed treatment } & Root length & Root volume & Root fresh matter & Root dry matter \\
\hline & $(\mathrm{cm})$ & $\left(\mathrm{cm}^{3}\right)$ & $(\mathrm{g})$ & $(\mathrm{g})$ \\
Control & $44 \mathrm{~b}$ & $91.2 \mathrm{~b}$ & $82.6 \mathrm{~b}$ & $23.7 \mathrm{~b}$ \\
Azospirillum brasilense & $67 \mathrm{a}$ & $189.0 \mathrm{a}$ & $167.0 \mathrm{a}$ & $32.5 \mathrm{a}$ \\
Captan fungicide & $47 \mathrm{~b}$ & $108.7 \mathrm{~b}$ & $96.9 \mathrm{~b}$ & $23.7 \mathrm{~b}$ \\
Thiodicarb insecticide & $50 \mathrm{~b}$ & $130.0 \mathrm{~b}$ & $102.3 \mathrm{~b}$ & $24.2 \mathrm{~b}$ \\
Captan + thiodicarb & $46 \mathrm{~b}$ & $117.5 \mathrm{~b}$ & $80.2 \mathrm{~b}$ & $19.9 \mathrm{~b}$ \\
A. brasilense + captan & $46 \mathrm{~b}$ & $114.2 \mathrm{~b}$ & $100.2 \mathrm{~b}$ & $16.3 \mathrm{~b}$ \\
A. brasilense + thiodicarb & $50 \mathrm{~b}$ & $58.7 \mathrm{~b}$ & $62.1 \mathrm{~b}$ & $17.9 \mathrm{~b}$ \\
A. brasilense + captan + thiodicarb & $49 \mathrm{~b}$ & $103.0 \mathrm{~b}$ & $79.2 \mathrm{~b}$ & $15.9 \mathrm{~b}$ \\
\hline CV $(\%)$ & 15.26 & 20.02 & 22.17 & 28.99
\end{tabular}

Mean followed by the same letter in the column do not differ by Dunnett's test at the 5\% probability level. 
Table 5. Effects of the application of captan (fungicide) and thiodicarb (insecticide) in association with the inoculation of Azospirillum brasilense on the relative chlorophyll index, leaf area, leaf dry matter, stem dry matter, total dry matter of corn seedlings (Zea mays L., cv. IPR 114). Guarapuava, Paraná, Brazil. 2014.

\begin{tabular}{lccccc}
\hline \multirow{2}{*}{ Seed treatment } & \multirow{2}{*}{$\begin{array}{c}\text { Relative chlorophyll } \\
\text { index }\end{array}$} & Leaf area & \multicolumn{3}{c}{ Dry matter } \\
\cline { 4 - 6 } & & & Leaf & Stem & Total \\
\hline Control & $52.4 \mathrm{~b}$ & $343.8 \mathrm{~b}$ & $16.5 \mathrm{~b}$ & $26.9 \mathrm{~b}$ & $43.4 \mathrm{~b}$ \\
Azospirillum brasilense & $58.7 \mathrm{a}$ & $466.4 \mathrm{a}$ & $24.2 \mathrm{a}$ & $32.8 \mathrm{a}$ & $57.0 \mathrm{a}$ \\
Captan fungicide & $51.2 \mathrm{~b}$ & $327.9 \mathrm{~b}$ & $18.2 \mathrm{~b}$ & $31.6 \mathrm{a}$ & $49.8 \mathrm{~b}$ \\
Thiodicarb insecticide & $53.7 \mathrm{~b}$ & $373.0 \mathrm{~b}$ & $17.5 \mathrm{~b}$ & $31.4 \mathrm{a}$ & $49.0 \mathrm{~b}$ \\
Captan + thiodicarb & $50.9 \mathrm{~b}$ & $322.4 \mathrm{~b}$ & $17.6 \mathrm{~b}$ & $27.4 \mathrm{~b}$ & $45.0 \mathrm{~b}$ \\
A. brasilense + captan & $53.5 \mathrm{~b}$ & $266.5 \mathrm{~b}$ & $16.1 \mathrm{~b}$ & $25.8 \mathrm{~b}$ & $41.9 \mathrm{~b}$ \\
A. brasilense + thiodicarb & $50.4 \mathrm{~b}$ & $372.9 \mathrm{~b}$ & $12.2 \mathrm{~b}$ & $28.5 \mathrm{~b}$ & $40.8 \mathrm{~b}$ \\
A. brasilense + captan + thiodicarb & $52.2 \mathrm{~b}$ & $341.1 \mathrm{~b}$ & $14.4 \mathrm{~b}$ & $25.8 \mathrm{~b}$ & $40.2 \mathrm{~b}$ \\
\hline CV (\%) & 4.47 & 12.95 & 19.71 & 15.64 & 21.29 \\
\hline
\end{tabular}

Mean followed by the same letter in the column do not differ by Dunnett's test at the 5\% probability level.

According to Battistus et al. (2014), the induction of plants involving metabolic costs promotes the need to complement this element in order to compensate for the extra consumption, thus explaining the variation in the values of the relative index of chlorophyll.

Although the chemical treatment of seeds helps control pathogens and pest insects during the sowing period, there is a need for evaluations of compatibility of fungicide and insecticide with inoculants containing diazotrophic bacteria. According to Campos et al. (2009), the main problem of seed treatment on the soil microbiota is due to the lower survival of the bacteria due to the active ingredient, $\mathrm{pH}$ and/or solvents used in the fungicide formulations.

\section{Conclusions}

The use of $A$. brasilense alone resulted in higher plant growth when compared to the uninoculated corn plants under greenhouse conditions.

The corn seed treatment with captan and thiodicarb interferes in the interaction of diazotrophic bacteria with the host plant, resulting in negative effects on germination rate and plant growth.

\section{Bibliographic References}

Battistus, A.G., Hachmann, T.L., Mioranza, T.M., Muller, M.A., Madalosso, T., Favorito, P.A., Guimarães, V.F., Klein, J., Kestring, D., Inagaki, A.M., Bulegon, L.G., 2014. Synergistic action of Azospirillum brasilense combined with thiamethoxam on the physiological quality of maize seedlings. African Journal of Biotechnology, 13, 4501-4507.

Brasil, 2009. Ministério da Agricultura e Reforma Agrária. Regras para análise de sementes. Brasília, 399 p.

Campos, R.J., Araujo, R.S., Hungria, M., 2009. Nitrogen fixation with the soybean crop in Brazil: compatibility between seed treatment with fungicides and bradyrhizobial inoculants. Symbiosis, 48, 154-163.

Cassán, F., Perrig, D., Sgroy, V., Masciarelli, O., Penna, C., Luna, V., 2009. Azospirillum brasilense Az39 and Bradyrhizobium japonicum E109, inoculated singly or in combination, promote seed germination and early seedling growth in corn (Zea mays L.) and soybean (Glycine max L.). European Journal of Soil and Biology, 45, 28-35.

Castro, G.S.A., Bogiani, J.C., Silva, M.G., Gazola, E., Rosolem, C.A., 2008. Tratamento de sementes de soja com inseticidas e um bioestimulante. Pesquisa Agropecuária Brasileira, 43, 1311-1318.

Dartora, J., Guimarães, V.F., Marini, D., Júnior, A.S.P., Cruz, L.M., Mensch, R., 2013. Influência do tratamento de sementes no desenvolvimento inicial de plântulas de milho e trigo inoculados com Azospirillum brasilense. Scientia Agraria Paranaensis, 12, 175-181.

Ferreira, M.M.M., Ferreira, G.B., Fontes, P.C.R., Dantas, J.P., 2015. Índice SPAD e teor de clorofila no limbo foliar do tomateiro em função de doses de nitrogênio e da adubação orgânica, em duas épocas de cultivo. Ceres, 53, 83-92.

Fey, R., Vogel, G.F., Martinkoski, L., Richart, A., Rampim, L., Klein, J., 2015. Fixação biológica de nitrogênio e efeitos do tratamento químico das sementes na sua eficiência, in: Kuhn, O.J., (Org.), Ciências Agrárias: Tecnologias e Perspectivas, primeira ed. Marechal Cândido Rondon, Universidade Estadual do Oeste do Paraná, p. 139-170.

Fibach-Paldi, S., Burdman, S., Okon, Y., 2012. Key physiological properties contributing to rhizosphere adaptation and plant growth promotion abilities of Azospirillum brasilense. FEMS Microbiology Letters, 326, 99-108.

Franche, C., Lindstrom, K., Elmerich, C., 2009. Nitrogenfixing bacteria associated with leguminous and nonleguminous plants. Plant and soil, 321, 35-59.

Gallori, E., Casalone, E., Colella, C.M., Daly, S., Polsinelli, M., 1991. 1,8-Naphthalic anhydride antidote enhances the toxic effects of captan and thiram fungicides on Azospirillum brasilense cells. Research in Microbiology, 142, 1005-1012. 
Hungria, M., 2011. Inoculação com Azospirillum brasilense: inovação em rendimento a baixo custo. Londrina: Embrapa Soja, 37 p. (Documentos, 325).

Hungria, M., Campo, R.J., Souza, E.M., Pedrosa, F.O., 2010. Inoculation with selected strains of Azospirillum brasilense and A. lipoferum improves yields of maize and wheat in Brazil. Plant and Soil, 331, 413-425.

Kintschev, M.R., Goulart, A.C.P., Mercante, F.M., 2014. Compatibilidade entre a inoculação de rizóbios e fungicidas aplicados em sementes de feijoeiro-comum. Summa Phytopathologica, 40, 338-346.

Milani, K., Santos, O., Silva, M., Leziér, D., Barreira, B., Oliveira, A., 2013. Influência do meio de cultivo sobre a população e produção de exopolissacarídeos por Azospirillum brasilense Ab-V5. Biochemistry and Biotechnology Reports, 2, 212-215.

Mohiuddin, M., Mohammed, M.K., 2013. Influence of fungicide (Carbendazim) and herbicides (2,4-D and
Metribuzin) on non-target beneficial soil microorganisms of rhizospheric soil of tomato crop. IOSR Journal of Environmental Science, Toxicology and Food Technology (IOSR-JESTFT), 3, 47-50.

Pereira, C.E., Oliveira, J.A., Oliveira, G.E., Rosa, M.C.M., Costa Neto, J., 2009. Tratamento fungicida via peliculização e inoculação de Bradyrhizobium em sementes de soja. Revista Ciências Agronômicas, 40, 433-440.

Reis Junior, F.B., Machado, C.T.T., Sodek, L., 2008. Inoculação de Azospirillum amazonense em dois genótipos de milho sob diferentes regimes de nitrogênio. Revista Brasileira de Ciência do Solo, 32, 1139-1146.

Vogel, G.F., Fey, R., 2016. Estímulo do potencial germinativo e fisiológico de centeio e triticale por Azospirillum brasilense, submetidos ao tratamento químico de sementes. Scientia Agraria Paranaensis, 15, 493-498. 